\title{
Irakasleak eta familiak etxerako lanetan: TIPSen estrategia
}

\author{
Garazi Esnaola Balerdi \\ Gizarte eta Hezkuntzako Eremuen Ikerketa Unibertsitate Masterra \\ Euskal Herriko Unibertsitatea UPV/EHU \\ José Francisco Amiama Ibarguren \\ Didaktika eta Eskola Antolakuntza Saila \\ Hezkuntza, Filosofia eta Antropologia Fakultatea \\ Euskal Herriko Unibertsitatea UPV/EHU
}

DOI: $10.1387 /$ tantak.17484

GAKO-HITZAK: Lehen Hezkuntza, etxerako lanak, proiektuetan oinarritutako ikasketak, familia-eskolaren arteko harremanak, eskola txikia, ikerketa-ekintza.

\section{SARRERA}

Etxerako lanak, familia, irakasle zein ikasleei kezka eta buruhauste ugari sortzen dizkien jarduerak dira. Eskola kontseilu, guraso elkarte eta talde ugariren artean sortu dira etxerako lanen inguruko zalantzak, aldaketa beharrak... komunikabideak ere arazo honen lekuko izan dira eta esan daiteke nolabaiteko egonezin bat sortzen duela gai honek hezkuntza komunitatearen baitan biltzen diren partaideen artean.

Euskaraz etxerako lan terminoaren baitan ere bada nolabaiteko nahasmen edo ezadostasun bat. Etxerako lanak edo etxeko lanak, egunerokotasunean bi adierak erabiltzen badira ere lan honek etxerako lan kontzeptua hautatu du lan honetarako. izan ere, etxeko lan hitzarekin badirudi etxeko eguneroko egin behar batzuez ari garela eta aldiz, etxerako lan kontzeptuak argiago adierazten du eskolako sistematik etxeko sistemara bidaltzen diren jarduerak direla. Etxerako lana adieraren sinonimo bezala berriz, eskolako lana erabiliko dugu honek ere zein sistematan sortua den lan hau argi uzten baitu.

Terminologia nahasteak argitu ostean, ikerlan honen motorra izango den ikerkuntza arazoa eskola txiki bateko testuinguruan kokatzen dela aipatu behar da. Bertan, gurasoek eskatzen die irakasle taldeari martxan dituzten ohiko etxerako lanei buruzko hausnartze prozesu bati ekiteko, ohiko 
etxerako lanen helburuak, diseinuak edo bidaltzeko tarteak ez zaizkie egokiak iruditzen hainbat gurasori.

Hausnartze bide horri ekitean, irakasleak etxerako lanen inguruko erabaki bateraturik ez dutela konturatzen dira, bakoitzak erabakitzen duela nolako lanak, noiz eta noizko egin behar dituzten bere ikasleek. Ondorioz, beraien lan metodologiarekin ez datozela bat jarduera hauek ikusten dute. Izan ere, normalean, proiekturen bidez lantzen dituzte gaiak, ikaslearen aurre ezagutzetatik abiatzen dira eta etengabe errealitateko egoerei erantzuteko gaitasunak lantzea dute helburu, etorkizuneko hiritarrak hezteko asmoz. Etxerako lanak aldiz, klasean amaitu ez dutena amaitzeko, eginiko errepasatzeko edota informazio ekartzea bezalakoak izan ohi dira. Inkoherentzia honi aurre egiteko beharra aurkezten zaio ikerlariari eta honek, lau ikerkuntza proposamen luzatzen dizkio irakasle taldeari.

Lau proposamenen artean TIPS (Irakasleek Gurasoen Inplikazioa Bultzatzea Etxerako lanetan) izeneko etxerako lanen aldeko apustua egin eta Ikerkuntza- Ekintza metodoak bideraturik irakasle eta ikerlariaren arteko elkarlanean etxerako lan hauek diseinatzeari ekiten die. Etengabeko ikaskuntza eta hobekuntza prozesu batean murgilduz, gurasoen iritziez baliaturik diseinuak moldatzen eta egokitzen jarraitzen baitute azken momentura arte.

Beraz, irakasle zein eskola komunitateko edozein partaideren interesekoa izango den ikerlan bat da datozen orrialdeetan xehetasun handiagoz azaltzen dena. Eskola jakin baten beharrei erantzuten badie ere, antzeko egoerak, kezkak bizi dituzten ikastetxeentzat ere lagungarri izango direlakoan gaude ikerlan honetako proposamenak. Ez dugu lortuko hezkuntza sistema errotik aldatzea, ezta etxerako lanen gaiaren eztabaida guztiak isiltzea ere, baina, hobekuntzen bidean bere hondar alea jarri nahi du lan honek. Elkarlanean eraikitako bide horiek gidatuko baikaituzte amesten dugun eskolara.

\section{MARKO TEORIKOA}

\section{Familia eta eskola harremana: Epsteinen eredua}

Eskola eraginkorrei buruz idatzi diren lanetan ere familiek eskoletan parte-hartzearen ideia azpimarratzen da. Eskolari onenek hezkuntza komunitatearen filosofia oso barneratua dute eta gelan soilik zentraturiko hezkuntza erreformek baino arrakasta gehiago lortu dute. Haurren garapena eta emaitzak hobetzeko ahaleginak eraginkorragoak dira familiarekin elkarlanean egiten badira. Baina, familien parte-hartze hori ahalbidetzea hein handi batean, eskolaren esku gelditzen da (Bolivar, 2006; Comellas, 2009).

Horrez gain, hezkuntza prozesuan familiak parte hartzearen onurak ikasleei eragiteaz gain, familia, eskola eta irakasleei ere positiboki eragiten die (Epstein, 2001; García Bacete, 2003; Valenzuela eta Sales, 2016). 
Ikerketa honek Epsteinen eredua izango du ardatz familiaren inplikazio hezkuntzan ulertzerako orduan. Eredu honek bi atal nagusi ditu: esferen eredua deiturikoa eta sei inplikazio mota zerrendatzen dituena.

Epstein eta bere kolaboratzaileek familien inplikazioa aztertzerakoan Brofenbrennerren (1987) teoria ekologikoa hartzen dute oinarritzat. Teoria honen ildotik, familia eta eskola sistemen arteko harremanak aztertzen dituzten haur edo nerabearen heziketa prozesuan eragiten duten bi sistema gisa ulertzen baitituzte. Familia eta eskolaz gain, hirugarren esparru edo esfera bat, ere aztertzen du eredu honek, komunitatearena, honek ere haurrarengan eragina duelakoan (Epstein, 2001; Epstein, Sanders, eta Sheldon, 2009). Aipaturiko hiru eremuak ardatz harturik, eskola komunitatea kontzeptua honela definitzen dute: Ikasle, guraso eta parte hartzen duten beste agenteei, eskola orduetan zein ondoren, zuzenduriko zerbitzu eta programak eskaintzen zaizkien espazioa (Epstein, 2001).

Heziketa prozesuan eragiten duten hiru esfera hauen arteko intersekzioen tamaina beti ez da berdina izango, hots, haurraren ongizatea bermatzeko elkarbanatzen dituzten espazioak handiago edo txikiagoak izango dira parte hartzen duten sistemen barnean hartzen diren erabakien arabera. Horregatik, familia eta eskola komunitatean dituzten espazioak gutxi badira, familia inplikazioa baxua dela esaten da. Intersekzioa zabalagoa denean aldiz, bi sistemen artean parte hartzea handiagoa dela adierazi nahi du, bi sistemen arteko hartu-emana estuagoa dela adieraziz.

Hainbat ikerlanen ondoren, Epsteinek familiaren inplikazioaren giltza eskolan eta zehazki irakasleek dutela ondorioztatzen du. Etxekoen eta eskolaren arteko elkarrekintzan bitartekari lanak egiten dituen subjektu gisa hartzen baita, bere jarreraren arabera familia eta komunitatearen parte-hartzea erraztu edo oztopatu baitezake. Arrazoi hau dela medio, irakasleek begirada aldatu behar dute eta lan egiterako orduan ikasleak bereak direla pentsatzetik haurra komunitate, familia eta eskolako partaide subjektu bezala ulertu behar du (Epstein, 2001; Epstein et al., 2002).

Familiek eskolarekiko duten interesa altua dutenean inplikazio maila hobetu egiten da. Aldiz, bai familiek bai eskolek euren zeregin eta betebeharrak zurrunago bete eta kolaboraziorako inolako jarrerarik aurkezten ez dutenean inplikazio maila kaskarragoa izan ohi da (Moreno, Estévez, Murgui eta Musitu, 2009).

Epsteinen ereduarekin jarraituz (Epstein, Sanders eta Shelon, 2009; Suárez, Regueiro, Tuero, Cerezo eta Rodriguez, 2014), familia eta eskolarekin zertan kolaboratu dezakeen zehazterakoan, sei motatako inplikazioak aurki ditzakegu. Honako hauek lirateke mota bakoitzaren ideia nagusiak.

1. Hazkuntza. Dimentsio honek haurren hazkuntzari loturiko aspektuak aztertzen ditu bereziki. Eskolak familiei euren oinarrizko egin beharretan laguntzen die, osasuna, segurtasuna bezalako gaiak ulertzen edota seme alabei eskolako lanetan nola lagundu edota etxeko 
ikaskuntzarako baldintza egokiak zein izan daitezkeen irakasten die. Parte hartze mota honetan sartuko lirateke, tutoretzak, eskolaren inguruko informazio saioak, osasuna edo higieneari buruzko ohar informatiboak, ikastaro edo hitzaldiak, guraso eskolak...

2. Komunikazioa. Kasu honetan, parte hartzea familia eta eskolen arteko komunikazioa harremana bezala ulertzen da. Familiak eskolari bere seme alabaren garapen fisiko, afektibo eta sozialari buruzko informazioa ematen dio, irakasleek martxan jarri beharreko programak egokitu edota ikasleen aurrerapausuen inguruko berri gehiago izan dezaten. Telefono deiak, gelako bilera edota sartu irteeretako konbertsazio informalak lirateke inplikazio mota honen parte.

3. Kolaborazioa eskolan. Familien boluntariotza lanetan oinarritzen da parte-hartze mota hau. Eremu eta lan ezberdin ugaritan kolaboratu dezakete, ikasleei laguntza eskainiz eskolaz kanpoko kirol jardueretan, festen prestaketa lanetan, kultur jardunaldien antolaketan, irteeretan, guraso elkartean edota Eskola Kontseiluan. Parte hartze mota hau eskolaren arabera oso ezberdina izan daiteke, esaterako, zenbaitetan gurasoek irakasleei ikasgai bat ematen laguntzen die (zenbait gurasok beren lanbidearen gaineko azalpenak eman, perkusio irakaslea den ama batek musikako saio bat prestatu...). Parte hartze mota hau beraz, guraso bolondresen araberakoa izateaz gain, eskola bakoitzaren antolaketaren araberakoa ere izango da.

4. Kolaborazioa komunitatean. Eskola kokaturik dagoen testuinguruak eragina du berarengan eta ondorioz, komunitate honek eskaintzen dituen baliabideak aprobetxatu behar ditu bere hezkuntza eskaintza hobetu eta osatzeko. Hau da, inplikazio mota honetan, eskolako eraikinetik haratagoko dinamikak burutzen dira eta familiaren parte hartzea ere beharko da zenbait ekintzatan. Honen adibide dira, auzoetarako hobekuntza proposamenak egitea, liburutegiko ordutegi eta erabileraren antolaketan parte hartzea, herriko edo auzoko festen antolaketan laguntzea, ingurumenaren inguruko udalaren sentsibilizazio kanpainetan parte hartzea...

5. Erabakiak. Zentroaren kudeaketa eta erabakitze organoetan parte hartzeari dagokio inplikazio mota hau. Hainbat ikastetxetan istiluak sortzen dituen parte hartze mota bada ere, legeak dio erabakitze organo hauetan familien iritziak ere eragin behar duela.

6. Etxeko ikaskuntza. Familiek euren seme alaben ikaskuntza prozesuan laguntzeko, eskolaz kanpo egiten dituzten jarduerak lirateke. Eskola familiei gelan eginikoari etxean jarraipena emateko eskaerak luzatzen dizkie, hau da, ikasteko ohitura hartzea, irakurtzea... Honek familia eta eskolaren arteko koordinazio lan garrantzitsua eskatzen du eta adibiderik ezagunenak, irakurketa, entziklopedia eta interneteko bilaketak edota ikerlan honetan aztergai ditugun etxerako lanak lirateke. Familien inplikazio handiena arlo honetan ematen da (Epstein 
eta Van Voorhis, 2001; Thin, 2009; Colás eta Contreras, 2013) beraien ardura delako ustetan (Epstein eta Van Voorhis, 2012).

Azken inplikazio mota honetan kokatzen da ikerlan hau, etxerako lanak baitira ardatz nagusia eta ondorengo atalean beraz, etxerako lanen gaia sakonago aztertuko da.

\section{Etxerako lanak}

Ikerketa hau egiteko aztertu diren dokumentuetan ageri den definiziorik aipatuena Cooperrena (2001) da, bere hitzetan etxerako lanak eskolako irakasleek ikasleei eskola orduetatik kanpo burutzeko jartzen dizkien jarduera oro dira. Ez dira multzo honetan sartzen ez eskolan egiten diren lanak, ez etxean beste baliabideen bitartez (bideoa, audioa, internet...) jasotzen diren klaseak eta ezta denbora libreko jarduerak ere (esaterako, eskolaz kanpoko kirol jarduerak). Definizio honek eskolan soilik jartzen du begirada, familia testuingurua ez du aipatu ere egiten «eskolaz kanpokoa» dioen horretan sartzen da.

Bestelako definizio bat aurkezten dute González, Carolina eta Reinak (1997) euren azterlanean, honela definituaz etxerako lanak: ikaskuntza formal bat testuinguru ez formalean. Ondoren, ikaskuntza honek ez duela zertan berria izan argitzen dute. Definizio labur honek ikaskuntzan eragiten duten bi sistema (formala eta informala) ezberdinen arteko konexioetan arreta jartzen du. Bi sistema hauek zeintzuk izan daitezkeen zehazten ez badu ere, eskola eta familia izan daitezke honen adibide.

Gimeno Sacristánek (2008), bi sistema hauen arteko konexioa beste modu batera aztertzen du. Eskolako denbora eta etxeko ikaskuntzaren arteko muga non ote den hausnartu eta zalantzan jartzen du. Bere hitzetan lehen begiratuan familia eta eskola sistemen mugak non bereizten diren argi dagoela uste da baina, honen inguruan pentsatu eta hausnartzen hastean, bi sistemen harremanak ez ditugula ondo ezagutzen eta hauen arteko mugak hasieran uste bezain argiak ez direla ikusten da.

Gai honi helduz autore berak gogoratzen du, eskolak ikasgaien egutegi zein ordutegiak ondo zehaztu eta mugatuak dituela dio eta arazoa, eskolak eskolarena ez den denbora, eskolarenak diren helburuak erdiesteko inbaditzen duenean sortzen dela. Izan ere, erakunde batek erabakitzen du berea ez den denbora hori (eskola ordutegiaren aurrekoa eta ondorengoa) bere jarduerak egiteko erabiltzea. Gainera irakaslearen presentziarik ez dagoen testuinguru eta denboraz ari gara, non zuzenean ezin dion laguntzarik eskaini ikasleari. Orduan, honako galdera hau luzatzen du Gimeno Sacristánek (2008): Zein informazio du irakasleak ikasleari laguntzen diotenei buruz edota dituzten baliabideei buruz? Hau $\mathrm{da}$, zenbateraino dute etxerako lan horiek bidaltzen dituzten testuinguruaren berri? 
Honengatik, hemendik kanpo, hainbat herrialdetan etxerako lanak hausnartuta eta araututa daude eskoletan (Cooper, 2001; Van Voorhis, 2003; Department of education and the arts Queensland Australia, 2004). Aldiz, espainiar estatuan eskola mailan ez da halako gomendiorik existitzen.

Posible da, ikastetxeetan dokumentu eta idatziz jasotzen diren gomendio hauen falta, hezkuntza departamentu mailako lege faltagatik izatea. Aurrez aipatu moduan, Espainia mailan legedi honen ausentzia are bistan gelditzen da 2010. urtean Nafarroako Arartekoak familien kexa bat aurkezten dionean Hezkuntza Kontseiluari ikasleen gehiegizko lan zamagatik. Urtebeteren ostean, aipatu dugun informea argitaratzen dute Nafarroako eskola kontseiluaren aldizkarian eta bertan eztabaidarako testu bat agertzeaz gain, irakasleentzako gomendio zerrenda bat ere ematen du (Ucar eta Iriarte, 2012:7).

«- Ikastetxeen autonomia esparruaren barnean, irakasle taldeak planifikatu eta koordinatuko ditu eta, orobat, bermatuko du mailakatuak izanen direla eta luzapen eta zailtasunean doitutakoak, maila bakoitzeko helburuei lotutakoak izanen direla eta irakasgaien arteko oreka mantenduko dutela.

- Kontuan izan behar dituzte ikasle bakoitzaren banakako beharrak eta lehentasuna eman behar diete oinarrizko ikaskuntza instrumentalei.

- Motibatzaileak izateaz gainera, ikasteko interesa eta zaletasuna sustatu behar dute.

- Argi eta zehatz azalduko da zer egin behar den, bai ikaslearendako, bai haren familiarendako.

- Begiratu, zuzendu eta kontuan hartu behar dira ikasleen irakaskuntza eta ikaskuntzako prozesuan.

- Ez dituzte klaseak ordezkatu behar eta ez dira zigor edo diziplinaneurri moduan inposatuko.

- Egoera ahulean dauden gizataldeendako ez dute elementu diskriminatzailerik sortuko haien bolumenagatik, egituragatik edo formagatik.

- Kontuan izanen dute ikasleek festa eta opor garaietan atsedena hartzeko duten beharra.»

\section{TIPS: etxerakorako lan interaktiboak}

Etxerako lan interaktibo hauek, ingelesezko Teacher Involve Parents in Schoolwork (TIPS), eskolan landu eta ikasitako gauza interesgarriak familiako kideekin, lagunekin edota komunitateko beste kideekin partekatzeko aukera eskaintzen die (Epstein, 2001). Irakaslearen garrantzia azpimarratzen da etxerako lanak diseinatzerako, ikasgai desberdinak kontuan hartuz. Jarduerak eraginkorrak izan behar dira, ikasleen motibazioa piztu eta kalitatezkoak izan beharko dute. Gainera maila baxu zein altuko ikasle orok egiteko modukoak izan beharko dute zeregin horiek. Horrez gain, edozein familiar laguntzeko bezalakoak izan beharko dute, edozein delarik ere beraien 
ikasketa maila. Irizpide hauek kontuan hartuz beraz, ikertzaile eta irakasleen artean etxerako lanen diseinua hobetzeko zenbait saiakera egin dituzte. Hauen artean, etxerako lan interaktibo gisa izendaturikoak daude. Azken finean, etxerako lanekin burutzen den ikaskuntza prozesuaren inguruko informazio bildu, familiaren parte hartzea bermatu eta ikaslearen ikaskuntza prozesuan eraginkorrak izango diren etxerako lanak diseinatzea dute helburu.

Ohiko etxerako lanetan bezalaxe, TIPS etxerako lanetan ere ikaslea da hau egiteko ardura duena eta familiek laguntzaile papera besterik ez dute izango. Laguntzaile rol honetan, etxerako lanetan proposatzen zaizkien eztabaidetan parte hartu edota ikasleen azalpenak entzutea izango da euren zeregina. Inongo momentutan ez zaie eskolan landu beharreko gaitasun edota ezagutzak irakastea eskatuko. Ikasleak izango dira klasean ikasi dutena etxean azaldu, ideiak familiarekin partekatu eta hauen iritzia idatziz jasoko dutenak. Egin beharren artean, etxekoen ideiak elkarrizketa bidez jasotzea, familien bizipen eta ohituren inguruan hitz egitea... daude. Azken finean, eskolan eskuraturiko gaitasunak errealitatean praktikan jartzeko aukera eskaini nahi du etxerako lanen diseinu honek, ikasitakoa hitzetan jarriaz.

Jarraitu beharreko prozedurari dagokionez, etxerako lanak bidaltzeaz haratago doan proposamen bat da eta hainbat irizpide kontuan izan behar dira. Lehenik eta behin, irakaslea izango da bai ikasle, bai familiei etxerako lan hauen inguruko informazioa eskainiko diena, zein pausu jarraitu, kontuan izan beharreko jarraibideak eman... Papereko diseinuari dagokienean, orri pare bateko luzera edo izan ohi dute, hasieran, ikasleak ulertu eta familiari azaldu beharko dizkion jarraibide sinple batzuk agertzen dira, era honetan umearen ulermen maila erakusten da; eta ondoren burutu beharreko zereginak. Etxerako lanaren helburua zein den, noizko egin behar den eta zein material beharko duten ere argi adierazita agertzen da. Materialari dagokionean, ikasle guztiek etxean dituzten materialekin egiteko moduko jarduerak diseinatzea funtsezkoa da, kontuan izan behar da, inolako baliabide edo material garestien beharrik ez izatea inor bazterturik sentitu ez dadin. Jarduerari dagokionez, ikasleak aurrez landu duena hitzetan jartzean datza, konstruktibismoaren ideiei jarraituz, aurre ezagutzetatik abiatuta eraiki nahi baita ikaslearen ezagutza. Egin beharreko jardueraren ondoren, familia-eskola komunikazioa izeneko atala egon ohi da. Bertan, gurasoek euren seme alabak etxerako lana egiterako orduan izan dituzten inpresioak, ikaslearen aurrerapausoak, beraien iritzia... adierazteko lekua dute. Ikerlan honetan informazio bilketarako ibiliko da atal hau, hiru galderako galdetegi itxi eta komentarioak gehitzeko galdera ireki batez osatuko delarik.

Maiztasunari dagokionez, etxerako lan hauek astean behin edo bitan erregularki bidaltzea gomendatzen da, ikasleek familiarekin eskolako gaiak partekatu eta lan egiteko ohitura bereganatu dezaten. Bidaltzen diren bakoitzean, lanak egiteko nahikoa denbora ematea garrantzizkotzat jotzen da familiak lasai ibili daitezen hauek burutzeko orduan, gomendioa bi egun baino gehiago uztea da. 
Behin ikasleek jarduera egiten dutenean, irakasleari bueltatzen diote eginikoa eta ohiko etxerako lanen moduan zuzentzen dira. Azkenik, diseinu berriak prestatzerako orduan familia eta ikasleen iritzietan oinarritzea gomendatzen da, ikaslearen beharretara egokitzeko (Epstein eta Van Voorhis, 2001).

Hiru motatako edukiak lantzen dituzte TIPSek. Hizkuntza, matematika eta zientzia.

\section{TITULUA: Etxeko uraren egoera ezagutzen}

GONBIDAPENA: Familia agurgarria: azken astean uraren inguruan aritu gara eta uraren egoerak landu ditugu. Espero dut nirekin batera jarduera hau egiten disfrutatzea

Egun honetarako egin behar dugu:

Maitasunez,

HELBURUAK: 1. Uraren egoerei buruz ikasia etxekoei azaltzea. 2. Etxean ura zein egoeratan eta non aurki dezakegun konturatzea.

MATERIALAK: Klaseko materialak diskurtsoa errazteko (ad. fotokopia bat)

PROZEDURA: Umeak kontatuko du TIPSa, klasean landutakoan oinarrituz

DATUEN BILKETA: Familia giroko jarduera batekin (ad. Non aurkitzen da ura zure etxean?; ura beti egoera likidoan dago zure etxean?

ONDORIOAK ETA EZTABAIDA: Zuen etxean ura erabiltzen duzuenean zein egoeratan erabiltzen duzue gehien?

FAMILIA ETA ESKOLAREN ARTEKO KOMUNIKAZIOA: Sistema familiarrean gertatzen dena jakiteko

Kaixo familia:Eskertuko nizueke, zuen seme/alabak jarduera honen aurrean izan duen erreakzioa ezagutaraztea galdetegi txiki honi erantzunez.

\begin{tabular}{|l|l|l|l|l|l|}
\hline $\begin{array}{l}\text { Zenbakien balorazioak: 1Erabat desados; 2 Desados; 3 Ez ados ez desa- } \\
\text { dosz; Ados; eta 5 Erabat ados }\end{array}$ & 1 & 2 & 3 & 4 & 5 \\
\hline $\begin{array}{l}\text { 1. Nire seme/alabak ulertu du jarduera eta etxerako lana } \\
\text { egiteko gai izan da. }\end{array}$ & & & & \\
\hline 2. Nire seme/alabak eta biok gozatu dugu jarduera honekin. & & & & \\
\hline $\begin{array}{l}\text { 3. Etxerako lan mota honek, eskolan inguruneko ikasgaian } \\
\text { zer ikasi duzuen hobeto ezagutzen lagundu dit }\end{array}$ & & & & \\
\hline
\end{tabular}

Beste komentariorik?

Familiako kidearen sinadura:

1. irudia

TIPSen diseinuaren adibidea 
Etxerako lan mota hauen inguruan egin diren ikerketek orokorrean emaitza positiboak izan dituzte (Epstein, 1997 ikus Epstein eta Van Voorhis, 2001). Ikasi da, bereziki hizkuntza eta zientziako TIPSak martxan jarri direnean urtebeteren buruan edo ikasleen errendimendu akademikoa hobetzea lortu dutela. Matematikakoetan aldiz, ez dira hain emaitza positiboak lortu (Epstein eta Van Voorhis, 2001).

Bestetik, familien aldetik balorazio oso positiboak jaso dituzte, bereziki etxerako lanei buruzko informazio gehiago jasotzen dutelako, euren seme alabei laguntzeak asebetetzen dituelako eta familien parte hartzeko aukera handitzen dutelako, baita maila sozioekonomiko baxuko familietan ere.

Egindako ikerketen errebisioan etxerako lan interaktibo hauen eragina positiboa dela azaltzen da. Badirudi baliagarriak direla haurraren lorpenak edo familia inplikazioa hobetzeko ez bada inbasio bat bezala bizitzen. Haurren adinari dagokionez, emaitza hobeak lortu dira Lehen Hezkuntzan egindako praktiketan Bigarren Hezkuntzakoetan baino (Patall, Cooper eta Robinson, 2008).

\section{METODOLOGIA}

Honako lana ikerketa-ekintza (I-E) bat da, prozesu zikliko batean oinarrituta (Bisquerra, 2009). Ikertzailearen rol gain jartzailea albo batera utzi eta aktore bilakatzea proposatzen da. Ikerketa kualititaboen ezaugarri den diseinu malgua izan du non etengabeko erabakiak hartzen diren hezkuntzaren arazo bati erantzun egoki bat emateko (Jolonch, 2005; Rekalde, Vizcarra eta Macazaga, 2011; Lukas eta Santiago, 2016) .

\section{Ikerketa galderak eta helburuak}

TIPS etxerako lanen baliagarritasuna eskola txiki batean ikertu nahi du azterlan honek.

Proiektu berri hau martxan jartzeko hainbat galdera sortu ziren: Gure ikastetxeko metodologiarekin koherenteak ote dira TIPS etxerako lanak? Erabilgarriak al dira eskola txiki batean? Nola diseinatzen dira TIPSak? Zer izan behar dugu kontuan hauek diseinatzeko? Zer nolako egitura dute? Garrantzirik ba ote du diseinuak? Zenbateraino lan zama dakarkio irakasle bati halako etxerako lanak diseinatzeak? Merezi ote du lan horrek? Eta honekin batera proiektu honen helburuak:

- Ikastetxeko metodologia ildoekin bat datorren etxerako lan mota baten saiakera martxan jartzea.

- TIPS etxerako lanen diseinuak irakasleentzat eskatzen duen esfortzua eta bere baliagarritasuna ezagutzea. 
- Familiaren iritziz honelako etxerako lanen erabilgarritasuna aztertzea.

Beste aldetik iker galdera asko sortu ziren: Ikasleak curriculumeko edukiak eta gaitasunak garatzerakoan laguntzen al dute etxerako lan mota hauek? TIPSak baliabide egokia ote dira klasean ikasitakoa barneratzen laguntzeko? Ikasleen ulermen mailan eragiten al dute? Ikasleen curriculumarekiko motibazioan zer nolako eragina dute etxerako lan hauek? Familia eskola harremana hobetzeko lagungarriak ote dira etxerako lan mota hauek? Familia-irakasle arteko komunikazioan modu positiboan eragiten al du? Familia ikastetxetik gertuago sentiarazten ote dute etxerako lan hauek? Zenbateraino laguntzen diote familiari beraien seme-alabek eskolan lantzen dutena ezagutzen? Seme- alabaren ikaskuntza prozesua gertuagotik ezagutzeko aukera ematen al dute? Familiek eskolako curriculuma ezagutzeko aukera bat al da? Familia barneko harremanetan eragiten al dute etxerako lan hauek? Zer nolako eragina dute? Ikasleen motibazioan zer nola eragiten du etxekoekin egiteak etxerako lan hauek? Familiako kideentzat zenbateraino lan zama dakar halako etxerako lanak bidaltzeak?

Hausnarketa honetatik helburu hauek sortu ziren:

- TIPSek ikasleekin curriculumeko eduki eta gaitasunak lantzea ahalbidetzen ote duten ezagutzea.

- Irakasle zein familien iritziz, ikasleen motibazioan etxerako lan mota hauek duten eragina ezagutzea.

- Familia- eskola harremana bi noranzkoetan hobetzea.

- Familiak, eskolako curriculumari buruzko informazio gehiago izatea.

- Irakasleak ikaslearen etxean jarraipena duen ikaskuntza prozesuari buruzko informazio gehiago jasotzea (ikasleen ulermen maila, familia harremana...).

- Familian honelako etxerako lanak burutzeak sortzen dituen gatazka, lan zama eta eskatzen duten esfortzua ezagutzea.

- Familiaren laguntzeko rola ezagutzea.

\section{Tresnak}

Eredu misto batetik, ikerketan zehar informazioa jaso eta emateko honako tresna ezberdinez baliatu dira kualitatibo zein kuantitatiboak erabili baitira, aspektu etiko eta konfidentzialak bermatuz (Blaxter, Hughes, eta Tight, 2008).

Ikerlan honetan behaketa parte hartzailearena erabili da, non, ikertzailearen rolak behatzaile hutsetik haratagoko zereginak dituen (Rekalde, Vizcarra eta Macazaga, 2014). Elkarrizketa teknika ere erabili da ikerketan, jarrera dialogikoei garrantzia handia ematen dizkielako (Gómez, Latorre, Sánchez eta Flecha, 2006). 


\begin{tabular}{c|ll}
\hline Tresna & Parte hartzailea & \multicolumn{1}{c}{ Aztertu den gaia } \\
\hline $\begin{array}{c}\text { Behaketa: } \\
\text { landa oharrak }\end{array}$ & $\begin{array}{l}\text { Tutoreak eta } \\
\text { ikerlari bat }\end{array}$ & $\begin{array}{l}\text { TIPSen diseinua (prozesua, oztopoak, } \\
\text { erraztasunak, esfortzua, denbora...) }\end{array}$ \\
\hline $\begin{array}{c}\text { TIPSeko galdetegia } \\
\text { (Epstein, 2001) }\end{array}$ & Familiak & $\begin{array}{l}\text { 1. Ikaslearen ulermena } \\
\text { 2. Familia-eskola harremana } \\
\text { 3. Familiar eta umearen motibazioa }\end{array}$ \\
\hline Elkarrizketa & Tutoreak & Prozesu osoaren balorapena \\
\hline $\begin{array}{c}\text { TIPSeko galdetegia } \\
\text { (ad-hoc) }\end{array}$ & Familiak & $\begin{array}{l}\text { 1. TIPSen erabilgarritasuna } \\
\text { 2. Hobekuntzarako proposamenak }\end{array}$ \\
\hline
\end{tabular}

2. irudia

Informazio bilketarako erabili diren tresnak

Kuantitaboki galdetegiak, eskala Likert bost aukerekin eskainiz, asko erabiltzen dira hezkuntza munduko ikerlanetan (Cuesta eta Hernandez, 2009). Lehenengoa, TIPSen autoreek sorturiko galdetegia da. Aldagi hauek neurtzen dira: umearen ulermena; familien gozamena; eta eskolako ezagutza. Galdera ireki batekin ixten da («Beste komentariorik»). Bigarrena berriz, familiak proposamena baloratzeko ad-hoc diseinatu egin zen 6 itemekin: familiarrak irakaslearen rolean; TIPSen erabilgarritasuna; TIPSen dedikazioa (denbora eta esfortzua); irakaslearekin harremana; eta eskolarekiko gertutasuna.

\section{Testuingurua eta parte hartzaileak}

Eskola Txikiak, landa eremuetan dauden eskolak dira. Herriko ia ume guztiak bertan eskolarizatuak egoten dira eta sei unitate(gela) baino gutxiago egon ohi dira Haur Hezkuntzatik, Lehen Hezkuntzari bitarteko ikasleak antolatzeko. Metodologiari dagokionez, testu libururik gabe eta proiektuen bidez landu ohi dituzte ikasgaiak. Gipuzkoan 26 eskola daude ezaugarri hauek dituztenak eta 1987az geroztik Eskola Txikien Koordinakundea deritzaion elkartearen baitan biltzen dira.

Kasu honetan, 600 biztanle inguru dituen landa eremuko herri txiki batean kokatzen den 80 ikasleko ikastetxea. Haur hezkuntzatik-lehen hezkuntzara bitarteko ikasleak bost taldetan antolaturik daude, eraikin bakarrean. Guztira 80 ikasleko ikastetxea da, herrian bertako eta alboko herri txikiagoko bateko haurrak doaz bertara. Landa eremuko herri txikia izanik, inguruan dagoen eskola bakarra da, publikoa eta D eredukoa. Hizkuntzari dagokionez, euskara nagusitzen da bai herrian baita ikasleen artean ere, 
gehiengoaren ama-hizkuntza oraindik ere euskara baita. Hala ere, aipatzekoa da azken urteetan, gaztelera edo atzerriko hizkuntza bat dutenen kopuruak gorantza jo duela. Eskola txikien ideologia eta metodologiaren barnean, ikasleak mailaka banatu beharrean zikloka daude antolatuak. Hau da, gela berean adin ezberdinetako ikasleak daude eta ohikoak dira etapen arteko jarduerak ere. Hau da, HHkoak LHkoekin zenbait saio egitea edota maila ezberdinetakoak nahasirik.

TIPS etxerako lanen proposamen berri hau Gipuzkoako herri txiki bateko eskola txiki batean kokatzen da, bertako elkar bizitza batzordean azaleratu baita ohiko etxerako lanen funtzionamenduaren inguruko kezka.

Zehatzago adieraziz, ohiko etxerako lanen erabilera ez zitzaien iruditzen beren eskolako pedagogia ildoekin bat zetorrenik. Izan ere, proiektuka lan egiten dute, testu liburuak erabili gabe, ikasleen jakin minetatik abiatuz eta dituzten beharrak asetuz. Horrez gain, komunitatearekin elkarlanean egiten dituzte hainbat jarduera, gurasoak eskolara etorriz, udalarekin elkarlanean... Aldiz etxerako lanetan, ohiko formatu eta helburuak mantentzen zituzten hau da, klasean amaitu ez dutenek jarduerak bukatzea, ikasitakoa errepasatzea, frogarako ikastea... Ondorioz, ikerketa honen helburu nagusia ez da eskola honetako etxerako lanen gaiaren inguruan sortu zaien arazoa deskribatzea soilik.

Etxerako lanei dagokienean, ikerketan parte hartuko dutenak Lehen Hezkuntzako 2. eta 3. zikloko ikasleak izango dira.

- Familiak: 2. eta 3. Zikloan dauden seme-alabak dituzten eskola txiki honetako familia guztiek parte hartu dute, 24 ikaslerenak (15 bigarren ziklokoak eta 9 hirugarrenekoak). Oro har, herrian bertan eta ondoko herri txikiagoko familiak dira, maila sozio-ekonomiko ertaina-altua dute eta hizkuntzari dagokionez, etxe guztietan gutxienez gurasoetako batek euskaraz badaki, familia batean izan ezik, etxeko ama hizkuntza bakarra gaztelania delarik. Etorkin kopuruari dagokionez, familia bakar bat da atzerritarra.

- Irakasleak: Ikerlan honetan, eskola txiki honetako 2. eta 3. zikloko bi tutorek, esperientzia handikoak eskola honetan, hartu dute parte, biak emakumeak eta ikastetxeko Bizikidetza programaren arduradunak. Horrez gain, zenbait gai elkarrekin burutzen dituzte bi ziklo hauetakoak.

Hauez gain, ikertzaile batek ere paper aktiboa izan du, ikerketa parte hartzailean ezaugarri den moduan partaideekin elkarlanean aritu baita.

\section{Prozedura}

Jarraitu den prozedurari dagokienez, I-Eko lau pausuetan (Latorre, 2003; Lukas eta Santiago, 2016) oinarritzen da: ekintza plana garatzea, 
ekintza plana martxan jartzea, eginiko ekintzen ondorioen behaketa eta ikerketaren mugei buruzko hausnarketa.

\section{Ekintza plana garatzea}

Ekintza plan bat sortu ahal izateko lehenik eta behin, arazoa identifikatu behar da, kasu honetan irakasleek euren eskolan duten etxerako lanei buruzko kezka azaleratzen dute. Hau da, egun martxan dituzten etxerako lanak egokiak ote diren ala ez hausnartzeko beharra sumatu dute eta bide bat ireki nahi izan dute irtenbide baten bila.

Ikastetxean, orain arteko etxerako lanak bidaltzeko honako irizpideak zituztela kontuan adierazten du klaustroak: 2. eta 3. Zikloetan soilik bidaltzen zirela eta opor egunetan ezin zela etxerako lanik bidali.

Arazoa esku artean izanik eta irtenbide posibleak pentsatuta, irakasle klaustroarekin bilera bat egiten da. Aipatu bezala beraiek proposatzen baitute ikerketa hau martxan jartzeko lehen kezka edo arazoa.

Lau proposamen egin eta gero, TIPS etxerako lan moten saiakera bat egitea erabakitzen dute. Familia-eskola harremana hobetzeko baliabide interesgarri eta egokia iruditzen baitzaie.

\section{Ekintza plana martxan jartzea}

Bi tutoreek eta ikerlariak taldea osatzen dute. Ikasgelan lantzen ari ziren gaia azaldu eta etxerako bidali nahiko luketena proposatzen zuten bi irakasleek eta ondoren talde lanean, TIPS etxerako lanen ezaugarrietara egokitzen ziren lan hauek.

Lehenengo diseinua egin ondoren, ikasleen etxerako lana bidali eta astebeteko epea zuten hauek egiteko. Etxerako lanak egin ostean, berriro ere bi irakasleak eta ikerlaria bildu ziren, lehenengo frogaren balorazio bat egiteko. Bertan, gurasoen komentario eta beraiek izan zituzten inpresioak kontuan hartuz, hobetu beharreko atalak eta mantendu beharrekoak erabakitzen ziren. Ondoren, bigarren diseinuari ekiten zitzaion eta horrela hiru egin bitartean. Prozesu zikliko bat izan da, TIPSen diseinuaren momentua, I-E metodoaren lau pausuetan murgildu dena bere baitan. Hau da, arazoak identifikatu, ondoren, diseinua nola hobetu pentsatu, gauzatu eta martxan jartzen zen. Etxerako lanak bueltatzean, hirugarren pausuari ekiten zitzaion, balorazioa egiten zen eta laugarrenean egiten den lez hurrengorako kontuan hartu beharreko ezaugarriak kontuan hartzen ziren. Honela etengabeko ziklo bat burutu zen TIPSen diseinua egokitzeko aburuz.

Azkenean, haur bakoitzak hiru aldiz eraman ditu TIPS motako etxerako lanak etxera. Guztira bost diseinu sortu dira, izan ere, ziklo bakoitzarentzat bat sortu da 1. eta 3. TIPSa bidaltzerakoan, gai ezberdinen inguruan ari baitziren. 2. TIPSa aldiz bi taldeentzat berdina izan zen, elkarrekin landu baitzuten gai hau eta ondorioz irakasleen eskariz biei berdina bidali zitzaien. 


\section{Eginiko ekintzen ondorioen behaketa}

Burututako diseinuen ondorioak ezagutzeko, hirugarren diseinua amaitu eta bidaliriko etxerako lan guztiak jaso ondoren, irakasleei elkarrizketa bat egin zitzaien, bi tutoreek prozesuaren inguruan hausnartu eta bildu dituzten etxerako lanetako emaitzak baloratzeko.

\section{Ikerketaren eragina eta mugei buruzko hausnarketa}

Denbora mugatua zela eta gurasoen emaitza hauek eta elkarrizketatik lortuak, ikerlariak aztertu baditu ere bere helburu nagusia datorren kurtsoan jarraipena emango dien prozesuan hausnartzeko datu batzuk biltzea izan da. Bertan, erabaki, eztabaidatuko baitute etorkizunera begira eman nahi dituzten hurrengo pausuak. I-E metodoaren zikloari jarraituz, inkesta hauetatik jasotako datuak familia zein gurasoekin batera aztertuz, dituzten arazoak identifikatu eta eman beharreko hurrengo pausuak zehazteko aukera izango dute, oraingoz irakasleek soilik jaso dituzten inkestetatik ateratako datuak.

\section{EMAITZEN ANALISIA ETA INTERPRETAZIOA}

\section{Irakasle eta ikertzailearen hitzetan TIPSen saiakera}

Behaketa parte hartzailean bilduriko landa oharrak eta azken elkarrizketan bilduriko ideiek, irakasleari TIPS etxerako lanen diseinuak prestatu eta martxan jartzeak suposatu diona ezagutzeko aukera ematen digu. Honela beraz, emaitzak aurkezteko lau kategoria nagusi sortu dira eta honen baitan beste azpikategoria batzuk.

\begin{tabular}{c|l}
\hline \multicolumn{1}{c|}{ Diseinua } & $\begin{array}{l}\text { Zailtasunak. Ikastetxeko metodologiarekiko harremana. } \\
\text { Talde lana. Asebetetze maila. }\end{array}$ \\
\hline Martxan jartzea & Ikasleen motibazioa. Gaitasun eta edukien lanketa. \\
\hline Balorazio orokorrak & $\begin{array}{l}\text { Erabilgarritasuna. Familien inpresioak. Ikasleen inpre- } \\
\text { sioak. Irakasleen espektatibak/emaitzak. }\end{array}$ \\
\hline Etorkizunari begira & Erronkak \\
\hline
\end{tabular}

3. irudia

\section{Behaketaren kategoriak eta azpikategoriak}




\section{TIPS etxerako lanak diseinatzen}

TIPSen diseinua ikastetxean egindako lau bileretan burutu da, ikerlaria TIPSen diseinuak beharko lituzkeen baldintzak azaltzean arduratzen zen eta ondoren, bi irakasleekin elkarlanean bi zikloetan lantzen ari zirenera egokitzen zituzten diseinuak. Ohiko etxerako lanekin alderatuz, TIPS etxerako lanetan garrantzia handiagoa hartzen du etxerako lan hauen diseinuak ondorengo ahotsak azaltzen duen moduan: "Ohiko etxerako lanak ez ditugu prestatu behar eta hauek prestakuntza bat eskatzen dute...» (T2z.1.18).

Irakasleek zailtasunak izan dituztela adierazten dute azken elkarrizketan: «... ezagutza aldetik ere bai aritu behar izan dugulako denentzat egokia izango dena prestatzen, umeak bere gisa moldatzeko modukoak...» (T2z.1.25).

TIPS etxerako lanen diseinuak denbora eta esfortzua eskatu die irakasleei, bilera ugari burutu dira hiruhilabetean eta etengabeko ikaskuntza prozesu batean murgildu behar izan dute.

Esfortzu bat egin behar izan duten arren esfortzu honen emaitza ikusi ahal izateak, ondo aprobetxaturiko denbora bat izan dela pentsatzera daramatza «... egia da guretzat berria den momentutik egin behar izan degula denbora bat eskaini eta denbora behar izan degula(...)»(T2z.2.04).

«...Neri iruditzen zait denbora bai eskatzen duela, ohikoak baino zerbait gehiago nolabait,baina, gustuko lan bat izan dela(...) Lehengo praktika askotan ikusten genuela ez zetorrela bat gure ildo teorikoekin edo izan beharko lukeenarekin. Honek aukera bat eman digu (...) izan beharko lukeeen hortara urbiltzeko(...). Ordun, denbora bai, ahalegintxo bat egin beharra bai baina, gustora.» (T3z.2.07).

Diseinuak denbora behar izateaz gain irakasleei aurrez hainbat ideia aurreikustea eskatzen die, kasu honetan, familien aniztasuna, ikasleen gaitasun ezberdinak edota eskura izan ditzaketen materialak kontuan izatea eskatzen da TIPSak diseinatzeko. Ikerlariaren landa oharretan jasotzen den moduan, irakasleei zailtasun gehien sortu dien atala izan da begirada aldaketa hau:

«...hegazkinez bidaiatu duten lekuak zerrendatzea eskatzen die ikasleei. Orduan, zenbait ikaslek agian sekula ez dutela hegazkin bat hartzeko aukerarik izan gerta daitekeela adierazi diot. Guztien izan behar dutela lan hauetan zeresana eta hegazkinez bidaiatzea ohikoa bihurtzen ari den arren eta ziurrenik ikaslerik gehienek egin badute ere, ikasgelako aniztasunari erreparatuz familia guztiek ez dutela horretarako baliabiderik ohartu gara...»(Ikerlaria). «...buru batek baino bik hobeto pentsatzen dute bati okurritzen ez zaiona besteari datorkio(...)» (T2z.2.09) 
Zailtasunak eta esfortzua izan arren, euren lan ildoekin bat datorren baliabide bezala definitzen dute. Testu libururik gabe lanketak, proiektuka lan egitera bultzatzen ditu horrez gain, elkarbizitzako planean familia-eskola harremanak sendotzeko erronka dutenez, diseinu hauek horretan laguntzen duela adierazten dute. "... hau ezagutu ondoren bestea utzi behar dugu albo batera eta honi heldu, hau izango da bidea» (T2z.3.06).

Diseinuari dagokionez, denbora, esfortzua eta hainbat zailtasunekin topatu badira ere, merezi izan duenaren sentsazioarekin gelditu dira biak. Azken finean euren lan ildoekin bat etorri izanak eta ikasle zein gurasoen erantzun positiboak jasotzeak, probetxugarria izan den lan bat egin dutela ikusarazi baitie. «... batik bat gurasoengandik jasotzen dezunean: oso egokiak iruditu zaizkigu, horrela jarraitzea nahi genuke, oso gustura aritu gara, beste arloetan ere nahi genuke... Gurasoek gogoko izatea guretzat oso garrantzitsua da, satisfakzio handia ematen digu.» (T3z.3.14).

\section{TIPS etxerako lanak martxan jarriz}

Etxerako lan hauen protagonistei buruz, ikasleek ikasgelan adierazi duten gogoa eta motibazio aipatzen dute bi tutoreek:

«...ikasle batzuek gainera oso garbi adierazi dute, pozik etorri dira lanak eginda Etxean aritu naiz aitarekin eta amarekin, familian aritu ginen egiten... ze ondo pozez txoratzen etorri zirela adierazten zuten... Nik uste beraiek ere oso gustora aritu direla.» (T2z. 3.21) «...Beraien artean komentatzen zuten: nik aitarekin egin det, nere ahizpak hau esan zuen... askoz joku gehiago eman du ohiko etxerako lanek baino ohiko etxerako lanek baino.» (T3z. 3.14) «...argi gelditu da gustura aritu direla eta nik uste azkenean gaian ere horrek izan duela bere eragina.» (T2z.3.27) «...ikasleek etxerako lan hauek gustura eraman dituzte, berria bezala ikusi dute eta etxekoekin aritzea gustatu zaie...» gehitzen du bigarren zikloko tutoreak.

Motibaturik egoteaz gain, ikaskuntza prozesurako baliabide egokia dela uste dute, bereziki, klasean landurikoa beste norbaiti azaltzeak ikasi dutena barneratzen laguntzen duela pentsatzen baitute euren lan ildoekin bat etorriz. «...oraindaino gure helburu bezala izan dugu azalpenak indartzea eta egin izan ditugu beste saiakera batzuk gela barnean, beste lan batzuk (...) iruditzen zaigulako ikasle horrek azaltzen jakiteak barneratzen laguntzen diola eta hemen beste eremu bat du azalpen bat emateko aukera eskaintzen dion Eta gainera berak oso gustoko duen inguru batean» (T3z.3.19).

Aipatzen dute, ohiko etxerako lanetan lantzen ez diren beste gaitasun batzuk lantzeko aukera ere ematen diela etxerako lan hauek, besteak beste, komunikazio gaitasuna edo ikastetxeko gaitasuna aipatzen ditu bigarren zikloko tutoreak. 


\section{Balorazio orokorra: TIPS etxerako lanak gure ikastetxean}

Egin duten esfortzuak merezi duela argi ikusi dute eta bereziki guraso eta ikasleengandik jaso dituzten emaitzak dira aurrera jarraitzeko indarra ematen diena: «familia, ikasleen aldetik emaitza positiboa izan dela ikusteak motibatzen gaitu (T2z.3.20). Ikusten da oraindik ibilbide bat egin behar dugula» "gehitzen du 3. Zikloko tutoreak, «...laguntza gabe hastean zeintzuk diren familia egin beharreko ariketak, galderak... pentsatzen hasteak zalantzak sortuko zaizkigu baina aurrera egingo dugu.» (T3z.3.12).

Ikasleengandik inpresio positiboak jaso dituztela esaten dute, arretaz eginiko lanak eta gogoa handia izaten zutela etxerako lan hauek burutzeko. Ohiko lanen kasuan, askotan lanak egin gabe ekarri ohi dituztela komentatzen zuen 2. Zikloko irakasleak baina aldiz, etxerako lan hauek guztiak eginak eta osatuak ekartzen zituztela adierazten zuen: «... dudarik gabe denek ekarri dituzte eginda eta ondo osatuta (...) zeren besteetan batzuetan ez dutela denborarik izan, ahaztu zaiela... hemen ikusten da nola interesa duten denak eginda ekarri dituztela...»(T2z.2.09). Hirugarren zikloko tutoreak arretarekin burututa daudela nabaritzen dela gehitzen du.

Gurasoen aldetik jasotako balorazioak positiboak izan direla azpimarratzen zuten bi irakasleek. Galdetegietan jasoriko erantzunez gain, zenbait gurasorekin etxerako lan hauen inguruan hitz egiteko aukera izan dute. Hainbat gurasok euren komentarioetan, «oso egokiak iruditu zaizkigu, horrela jarraitzea nahi genuke, oso gustura aritu gara, beste arloetan ere nahi genuke..» (F20.3z.3). bezalako komentarioak jaso dituztela adierazten dute bi tutoreek.

Landu dituzten gaiekiko baino motibazio handiago sortu duela familian aritu behar izateak adierazten dute: ... Neri iruditzen zait gai bat edo bestea izan, motibazio gahiago sortu duela era horretan egiteak lanak. Modu honetan, familiarekin lan egitea izan dute gogoko, gai bateko zein bestearekin (T3z.3.05).

Gurasoen jarrerak ere ikasleengan eragin nabarmena duela aipatzen du 3. Zikloko irakasleak, ikasleak nabari baitu gurasoek lan hauekiko duen interesa: «...Gurasoek harrera ona egin badie askoz hobeto erantzuten dute ikasleek ere, gurasoen onarpen eta interes hori baitute...» (T3z.2.24).

Hirugarren zikloko tutoreak berriz, ikasleen autonomian eragiten dutela, azpimarratzen du, etxerako lan hauek eta bere iritziz ikaslearen rol aktiboa bultzatzen dutela: «Hauek gehiago adierazten dute besteek baino. Beste lanak bidaltzen dituzu baina ez dakizu etxean zer gertatu den, zergatik egin dituen, zergatik zuzen, zergatik gaizki... eta hemen nik uste honen kontrola ikasleak berak duela» (T3z.3.11).

Azkenik sorpresa handirik egon ez arren, espero baino emaitza hobeak bildu dituztela adierazten dute, guraso guztiek parte hartu baitute bai euren iritziak helaraziz bai seme-alabekin etxerako lanak eginez, honela adierazten du 2. Zikloko irakasleak: «...orokorrean nahiko gustura eta adie- 
razi dute horrelako lanak gustuko dituztuela, gustura sentitu direla. Nik pentsatzen nuen erantzungo zutela eta uste baino hobeto erantzun dute.» (T2z.3.17)

Familia-eskola harremana gaiari dagokionez, euren erronketako bat dute hori sendotu eta hobetzea. Horren harira, TIPS etxerako lanak erabilgarriak iruditu zaizkie harreman honetan eragiteko.

\section{Etorkizunari begira}

Datorren ikasturteari begira, etxerako lan hauek arlo guztietan aplikatzearen aldeko apustua egin nahi dutela azaltzen du hirugarren zikloko tutoreak: «...gustatuko litzaidake era horretan aritzea arlo guztietan eta nolabait eguneroko praktika bihurtzea hori gure ildo nagusiei zuzen zuzenean eragiten dielako. Horretan saiatuko gara. Gure asmoa da aurrerantzean hemen ikasitakorekin eta ikasten goazen eran, mota honetako etxerako lanak zalbaltzea arlo guztietan eta beste irakasle eta espezialistekin elkarlanean enfoke hau ematea gure eskolako etxerako lan guztiei. Eta hori azaltzea gure A.J.A.n, jarduera araudian.» (T3z.3.27)

Amaitzeko, ikerlan honek etxerako lanei buruz egiten ari ziren hausnarketan bultzada handi bat eman ziela adierazten dute: «guraso batzuek honen inguruan hausnartzeko eskatu zigutelako sortu zen ideia hau eta lan honek bultzada eman digu aurrera begira lanean jarraitzeko.» (T3z.3.18).

Ikerketaren atal kuantitatiboari dagokionez, aipatu bezala familien ikuspegia ezagutzeko bi inkesta burutu dira. Bata, prozesuan zehar etxerako lan bakoitzarekin batera (hiru alditan) eta bestea prozesua amaitu ondoren. Ikerketa honen parte hartzaile kopurua oso txikia izanik, galdetegi hauetan ateratako datuen bitartez ikastetxeko honetako familien iritzian joera bat nabaritzen ote den ikusi nahi da eta neurri deskribatzaileak aurkeztuz: frekuentzia, moda, bataz-bestekoak eta minimo/maximoak. Lehenik eta behin prozesuan zeharreko «familia-eskola komunikazioa» izeneko galdetegian bilduriko emaitzak aurkezten dira eta jarraian, prozesu amaieran pasa den galdetegiarenak.

\section{TIPSeko galdetegia}

Bilduriko emaitzak jarraian ikusgai den taulan laburbiltzen dira. Aipatu behar da, 2. TIPSak 2. eta 3.zikloan diseinu bera izan zuela, irakasleek horrela eskatuta.

Taula honetan 2. Zikloari dagozkien datuei erreparatzen badiegu puntuazioen joera altua da aldagai guztietan, burutu diren 3 TIPSen moda 5 (erabat ados) izan da lehenengo TIPSeko «elkarrekin gozatu» eta «Eskolan ematen dena ezagutzea» itemetan izan ezik. Puntuazio minimoei errepara- 
tzen badiegu lehenengo TIPSean $2 \mathrm{ko}$ bi puntuazio ageri dira eta familia berarenak direla adierazi behar da.

3.zikloan ere modari erreparatzen badiogu, 4-5 puntuazioen artean kokatzen dela ikusten da. Puntuazioen joera hemen ere altua da aldagai guztietan, 3,93 da bataz besteko baxuenaren balioa. Puntuazio baxuenei erreparatzen badiegu, 2. TIPSean agertzen da kasu bat baina 3ko puntuazio bat du eta 3. TIPSean «Elkarrekin gozatu» itemean bakar bat kokatzen da 1eko puntuazioan.

2. eta 3. Zikloan egin duten TIPS berari erreparatzen badiogu, TIPS 2ari, datu zuzenetan frekuentziak antzeko direla ikusten da.

\begin{tabular}{|c|c|c|c|c|c|c|c|c|c|c|}
\hline \multicolumn{11}{|c|}{ TIPS GALDETEGIAK (Prozesuan zehar) } \\
\hline & & \multicolumn{5}{|c|}{ Frekuentziak } & \multirow{2}{*}{ Media } & \multirow{2}{*}{ Moda } & \multirow{2}{*}{ Minimoa } & \multirow{2}{*}{ Maximoa } \\
\hline & & 1 & 2 & 3 & 4 & 5 & & & & \\
\hline \multicolumn{11}{|c|}{ 2. ZIKLOA } \\
\hline \multirow{3}{*}{ 1. TIPS } & Ulermena & 0 & 0 & & 6 & 7 & 4,33 & 5 & 3 & 5 \\
\hline & Elkarrekin gozamena & 0 & 1 & 2 & 9 & 3 & 3,93 & 4 & 2 & 5 \\
\hline & Eskolako ezagutza & 0 & 1 & 1 & 8 & 5 & 4,13 & 4 & 2 & 5 \\
\hline \multirow{3}{*}{ 2. TIPS } & Ulermena & 0 & 0 & 3 & 1 & 10 & 4,89 & 5 & 4 & 5 \\
\hline & Elkarrekin gozamena & 0 & 0 & 4 & 2 & 6 & 4,78 & 5 & 4 & 5 \\
\hline & Eskolako ezagutza & 0 & 0 & 2 & 3 & 7 & 4,78 & 5 & 4 & 5 \\
\hline \multirow{3}{*}{ 3. TIPS } & Ulermena & 0 & 0 & 2 & 1 & 11 & 4,71 & 5 & 3 & 5 \\
\hline & Elkarrekin gozamena & 1 & 0 & 3 & 5 & 5 & 4,29 & 5 & 3 & 5 \\
\hline & Eskolako ezagutza & 0 & 0 & 0 & 8 & 6 & 4,48 & 5 & 3 & 5 \\
\hline \multicolumn{11}{|c|}{ 3. ZIKLOA } \\
\hline \multirow{3}{*}{ 1. TIPS } & Ulermena & 0 & 0 & 0 & 1 & 8 & 4,33 & 5 & 3 & 5 \\
\hline & Elkarrekin gozamena & 0 & 0 & 0 & 2 & 7 & 3,93 & 4 & 2 & 5 \\
\hline & Eskolako ezagutza & 0 & 0 & 0 & 2 & 7 & 4,13 & 4 & 2 & 5 \\
\hline \multirow{3}{*}{ 2. TIPS } & Ulermena & 0 & 0 & 1 & 1 & 7 & 4,89 & 5 & 3 & 5 \\
\hline & Elkarrekin gozamena & 0 & 0 & 1 & 3 & 5 & 4,78 & $4-5$ & 1 & 5 \\
\hline & Eskolako ezagutza & 0 & 0 & 1 & 2 & 6 & 4,78 & 4 & 4 & 5 \\
\hline \multirow{3}{*}{ 3. TIPS } & Ulermena & 0 & 0 & 0 & 1 & 8 & 4,71 & 5 & 0 & 5 \\
\hline & Elkarrekin gozamena & 1 & 0 & 0 & 5 & 4 & 4,29 & $4-5$ & 0 & 5 \\
\hline & Eskolako ezagutza & 0 & 0 & 0 & 1 & 7 & 4,48 & 5 & 0 & 5 \\
\hline
\end{tabular}

4. irudia

TIPSen galdetegiko datu deskribatzaileak

TANTAK, 28 (2), 2016, 149-174 orr. 


\section{TIPS prozesua baloratzeko galdetegia}

Familiaren balorazioaren inguruko ideia bat egiteko helburuz deskripzio datu nagusiak aurkezten dira.

Taula honetako datuak erreparatzean ere puntuazioen joera altua ikuste daiteke. Lehen aldagaiak « Gurasoak irakaslearen paperean» gurasoek ea irakaslearen papera jokatu duten ala ez adierazten du. Bertan, batezbestekoak 3,42 ko balioa du eta frekuentzia baxuetan 3 familia kokatzen dira.

Bigarren itemari dagokionez, «erabilgarriak dira» moda 4ean kokatzen da eta puntuazio baxuetan 2 familia kokatzen dira. «Denbora eta esfortzua» izeneko aldagaian berriz, 7 dira puntuaziorik baxuenetan kokatzen direnak eta bataz bestekoak 3,38ko balioa du.

«Irakaslearekin harremana» hobetzeko itemean berriz, 3,14ko bataz bestekoa agertzen da, puntuazio baxuetan 5 eta altuenetan 7 familia daudelarik. Azkenik Eskolatik gertuago sentitu aldagaian, 3,57ko balioa du batazbestekoak eta 24tik 4 dira puntuazio minimoetan kokatzen diren familiak.

\begin{tabular}{l|rrrrr|rrrrr}
\hline \multicolumn{7}{c}{ Prozesuaren balorazioa gurasoen galdetegia (2. eta 3. ziklokoak) } \\
\hline & \multicolumn{7}{|c}{ Frekuentziak } & & & \\
\cline { 2 - 7 } & 1 & 2 & 3 & 4 & 5 & & & & \\
\hline Familiarrak irakaslearen rolean & 2 & 1 & 8 & 11 & 2 & 3.42 & 4 & 1 & 5 \\
Erabilgarriak & 1 & 1 & 4 & 9 & 8 & 3.96 & 4 & 1 & 5 \\
Denbora eta esfortzua & 0 & 7 & 5 & 8 & 4 & 3.38 & 4 & 2 & 5 \\
Irakaslearekin harremanak & 2 & 3 & 10 & 4 & 3 & 3,14 & 3 & 1 & 5 \\
Eskolatik gertuago sentipena & 1 & 3 & 5 & 10 & 4 & 3,57 & 4 & 1 & 5 \\
\hline
\end{tabular}

5. irudia

Familien azken balorazioko datu deskribatzailea

\section{Familiaren iritzia TIPSen galdetegien bitartez}

Irakasleen iritziaz gain ikerketaren atal kualitatiboak familien iritzia ere jasotzen du. Horretarako, TIPSen diseinuaren baitan datorren galdetegiaren azken galdera irekian bildutako komentarioak zerrendatzen dira jarraian. Esaldi hauek, galdetegiko itemetan oinarrituta sorturiko hiru dimentsio edo kategoriatan sailkatu dira: ulermena, gozamena eta eskolako curriculumaren ezagutza izenekoetan hain zuzen ere. 24 ikasleren familietan hiru aldiz pasa diren galdetegietan azken galdera ireki honi emandako erantzunak 13 izan dira. Horietatik 11 komentario positiboak direla esan behar da, hiru kategoria hauetan antolatuta. 
- Ulermena: Gaurkoa oso errez egin dugu. Ondo dagoela mundua ezagutzeko.(F7.2z.3)

- Gozamena: Oso gustora aritu gara lan honetan (xxx). Hasiera batean debereak bezala hartu ditu eta behartuta egiten hasi da. Gero Google maps-en hasi gara eta gauza desberdinak eta leku desberdinak ikusi gustura egon gara. Umeari esplikatzen non egon garen, noiz eta nola. Gauza horiek konpartitu ditugu. (F12.2z.2)

- Eskolako ezagutza: Lan hauek direla medio, eskolan lantzen dutenaz gehiago jakiten dugu. (F19.3z.1)

\section{ONDORIOAK}

TIPS delako etxerako lanak izango dira ikastetxe honetan martxan jartzen direnak, izan ere, ikastetxean testu libururik gabe eta proiektuen bidez egiten dute lan, adin ezberdinetako ikasleen arteko elkarlana bultzatuz. Noranzko honetan, TIPS etxerako lanak haurraren aurrezagutzetatik abiatzen dira eta eskolan landua etxeko errealitatean praktikan jartzeko asmoa izan ohi dute, proiektu txikiak direla esan daiteke. Ikasi duena azaldu eta familiako kideekin partekatzeak du garrantzi handia (Epstein, 2001).

Familia inplikatzeko bide honetan, irakaslearen paperak garrantzia handia hartzen du. (Bolivar, 2006; Comellas, 2009). Horrexegatik lan honetan, irakaslearen rolak ikerketaren zati handi bat hartzen du. Bi hilabeteko prozesuan zehar irakasleek elkarlanean TIPS diseinu ezberdinak burutu baitituzte. Horretarako etxerako lan mota honen ezaugarri nagusiak ezagutu eta praktikan jarri behar izan dituztelarik bilera ezberdinetan. Diseinuak sortzeko une hauetan aurkitu duten zailtasun aipatuena, gela eta familia aniztasunari egokitzearena izan da. Hau da, ikasle guztiek edozein etxetan egiteko diseinuak sortzean izan dituzte zailtasun gehien. Hala ere, bi tutoreek aipatzen dutenez, asko ikasi dute prozesuan zehar eta orain euren kabuz ekin behar die bideari, ikertzailearen galdera eta laguntzarik gabe ikasle guztientzat erabilgarri izango diren diseinuak sortuz.

Ohiko etxerako lanetako prestakuntzarekin konparatuz, hasierako diseinuan, TIPSek lan gehiago ematen dute. Baina familia eta ikasleengandik erantzun ona jasotzen denez lan hori era baikor batean baloratzen da.

Familien kasuan ere etxerako lan hauen gaineko komentario eta balorazio positiboak egin dituzte. Jasotako galdetegien puntuazioetan joera positiboa da eta horrela jarraitzeko, gustura egin dituztela, arlo gehiagotara zabaltzeko edota eskolan lantzen dutenaren berri izateko aukera ematen diela adierazten dute.

Beste ondorio interesgarria da bi sistemen arteko harremanen hobekuntza. Familia eta eskolen arteko harremana areagotu eta hobetu egin dira etxerako lan hauen bitartez. Gai honen baitan irakasleek ere etxean gertatzen denaren berri gehiago jasotzen dutela modu honetara elkar jartzen di- 
ren esferen teoriarekin bat etorriz, bi sistema ezberdin baitira elkarrekin konexioak dituztenak, elkarrekin konektaturiko gune horiek sistema batean eta bestean gertatzen dena argitzen laguntzen dutelarik, honen adibide dira, TIPS etxerako lanak ere (Epstein, 2001).

Orokorrean familia zein irakasleen balorazioa oso positiboa izan da, guztiek azpimarratu dute etxerako lan hauen erabilgarritasuna eta familiaeskola harremanean duen eragina. Haurren aldetik ere, bai irakasle bai gurasoek orokorrean gustura aritu diren sentsazioa izan dute. Haurra motibatzeaz gain, bi sistemen arteko elkarlanak sistema ezberdinentzako onurak ere badakartza. Ondorioz, TIPS etxerako lanak eskola txiki honetan erabilgarriak izan direla ondorioztatu daiteke, ikasleen ikaskuntza prozesuan zein eskola-familia harremanean modu positiboan eragin duelarik.

Orain artean ikerlanaren lorpenak eta alderdi positiboak nagusitu badira ere, ikerlan honek izan ditu bere muga eta aurrera begira hobetu beharreko puntuak ere. Hasteko, marko teorikoa osatzerako garaian, estatu mailan, orokorrean etxerako lanen gaiaren inguruko informazio zientifiko handiegirik ez da topatu. Badirudi, gutxi ikertu den gaia izan dela edo ez dela gauza handirik publikatu gai honen inguruan.

Argitu behar da, ikerketa hau irakasleen beharretatik abiatzen dela eta irakasle taldeak izan zuela ikerketaren nondik norakoak hautatzeko azken hitza. Hori dela eta, inongo momentuan etxerako lanak egon behar ote luketen edo ez luketenaren eztabaidari ez zaio heldu inongo momentuan. Ikastetxe honetan, erabakia zuten etxerako lanak egongo zirela eta beraien erronka hauek euren ildo metodologikoetara egokitzea zen. Horrexegatik, baldintza horretatik abiatzen da ikerketa eskolaren beharrei erantzutea baitu helburu.

Lan honetan bertan, sarritan aipatu den bezala ikerketa honetako datuak ez dira orokortzeko modukoak, lagina oso txikia izateak bereziki ikerketaren alderdi kuantitatiboan azterketa sakonik ezin egin izana ekarri du. Hala ere, lorturiko emaitzak aurrez beste herrialde eta ikerketan eginiko ikerketen emaitzekin bat datoz (Van Vorhis, 2004), positiboki baloratzen baita hauen erabilera hemen ere. Dena dela, adierazi behar da galdetegi hauek denbora faltagatik egin ez genuen talde eztabaidaren ordez familien ikuspegia jasotzeko asmoz egin direla. Aurrera begira datu hauek erabili nahi dira bertan burutuko diren talde eztabaidetan guraso zein irakasleekin erantzun dituzten galdetegien emaitzak aztertu eta hausnarketarako bidea irekitzeko.

Esan behar da, etengabeko berrikuntzan murgildu eta berriro ere I-E diseinu bat burutzeko bultzada bat izan direla lorturiko emaitza positiboak. Hasteko, TIPS hauen bitartez irakasleek ikasleen ulermen mailari buruz informazio gehiago eskuratzeko aukera dutela ikusi da. Irakasleak etxerako diren jarduera hauen inguruko kontrol handiagoa eta informazio gehiago eskuratzeko aukera baitu. Irakasleei informazio gehiago eskaintzeaz gain, familiek ere eskolan gertaturikoa ezagutzeko aukera izaten dute eta eskolako curriculuma ezagutzeko baliagarri egiten zaie. Informazio truke honetan abantailak ekartzeaz gain, ikastetxerako lan ildoekin eta proiektu bidez 
lan egitearekin bat datorrela ikusi da, bere baitan proiektu txikiak baitira TIPS etxerako lanen diseinuak. Horrez gain, irakasleei talde lanean jarduteak abantaila ugari ekarri dizkiela ikusi da eta bestek beste, zikloen artean ere etxerako lan hauek konpartitzeko aukera lagungarria izan da irakasleentzat. Ikaskuntza irakaskuntza prozesuan eraginkorrak izatez gain, ikasle zein familien motibazioa ahalbidetu dutela dirudi eta era berean, familia hauek eskolatik gertuago sentitu direla adierazten dute. Onurez gain, arriskuak ere badirela aipatu behar da, besteak beste, familiei diseinu hauek familiei denbora eta esfortzua eskatzen diela ikusten da. Honen aurrean, etengabeko komunikazio bat mantentzea irakasle eta familien artean funtsezko izango da alderdi hau hobetzen joan ahal izateko. Horrez gain, familia ugarik irakaslearen papera hartu dutela adierazten dute galdetegietan eta hau ez da oso egokia, sistema bakoitzak bere funtzioak izan behar baititu. Hori dela eta, guraso eskolak edo formazio saio batzuk izan litezke honen irtenbide, familiei izan behar duten laguntzaile papera nolakoa den argi adieraziz.

Onurak eta arriskuak ezagutu ondoren, irakasleek familia eskola harremana etxerako lanen bitartez hobetzeko proiektua martxan jarriko dutela adierazten dute. TIPSen erabilera eurenganatu eta arlo ezberdinetan egiten diren etxerako lanak diseinu eta helburu hauek izatea nahi dute. Ikerkuntza-Ekintza hau beraz, martxan jarri den prozesu baten hasiera baino ez da izan, ikertzen eta ekiten jarraitzeko bide ugari ireki dituena.

\begin{abstract}
This piece of research tries to answer to a need issued by the parents and the teachers of a small rural school considering homework given to children. Realizing failure of traditional homework activity, they aimed to build up an approach that would improve the relationship between the school and its families and be coherent with their educational methodology. Consequently, Epstein's homework related interactive process called TIPS (Teachers Involve Parents in Schoolwork) has been initiated. This approach gives the opportunity that children could share with their families all those interesting aspects they have worked on and learned at school. Together with the support of an external researcher, two participant teachers created and went through a 3 cycles of a TIPS designed process aimed to Primary Education students of the following years: Y8, Y9, Y10 and Y11. Qualitative data was gathered through observation and interviews carried out with two tutors. Quantitative information came from 24 participant
\end{abstract}


family members through survey that was filled at home. Taking into account the family diversity, results of the evaluation of TIPS process have been positive as the three groups involved express a higher satisfaction level concerning: the availability of relevant information for tutors; school and family relationship; interactions among children and their families and students' motivation with this type of homework.

Keywords: Primary school, homework, Epstein's proposal for interactive homework, family-school relationship, rural school, action research.

Este trabajo responde a una necesidad de profesorado y familias de una escuela rural sobre los deberes escolares. Quieren que sean acordes con el planteamiento metodológico de la escuela y que mejoren las relaciones familia-escuela. Para ello se ha recurrido a la propuesta de Epstein sobre deberes escolares interactivos (TIPS). Estas tareas dan la oportunidad de compartir con los miembros de la familia aspectos interesantes de lo trabajado y aprendido en la escuela. El objetivo de esta propuesta de investigación-acción, ha sido el de crear y revisar 3 tareas TIPS para el segundo y tercer ciclo (alumnado de 9 a 12 años) contando con el apoyo de una investigadora externa. La información cualitativa (observación y entrevista en la escuela) se ha recogido a través de las dos tutoras mientras que la cuantitativa (cuestionario en casa) ha sido aportada por las 24 familias implicadas. Teniendo en cuenta la diversidad familiar, los resultados señalan mayores grados de satisfacción en los tres colectivos: disponibilidad de información relevante para los tutores, percepción en la relación familia-escuela, interacción con los hijos y motivación del alumnado con este tipo de deberes escolares.

Palabras clave: Educación Primaria, tareas para casa, propuesta de Epstein para deberes escolares interactivos, relación escuelafamilia, escuela rural, investigación-acción.

Ce travail répond à une nécessité du professorat et des familles d'une école rurale sur les devoirs scolaires. Ils/elles veulent que ces devoirs soient compatibles avec l'approche méthodologique de l'école et la famille et qu'ils servent à améliorer les relations famille-école. Voilà pourquoi on a choisi la proposition d'Epstein à propos des devoirs scolaires (TIPS). Ces tâches donnent l'opportunité de partager avec les membres de la famille des aspects intéressants de ce qu'on a travaillé et appris à l'école. L'objectif de cette proposition de recherche-action a été créer et vérifier trois activités TIPS pour le deuxième et troisième cycles (des élèves de 9 à 12 ans) avec le soutien d'une chercheuse externe. L'information qualitative a été recueillie avec les deux tutrices (observation et interview à l école) et la quantitative a 
été fourni par les 24 familles concernées (questionnaire á la maison). Les résultats montrent des niveaux plus élevés de satisfaction parmi les trois groupes, en prenant en compte la diversité de la famille, ils ont été les suivants: la disponibilité des informations pertinentes pour les tuteurs, la perception de la relation famille-école, l'interaction avec les enfants et la motivation des élèves avec ce type de devoirs.

Mots-clé: Ecole primaire, devoirs scolaires, proposition Epstein pour les devoirs interactive, relation parents-école, école rurale, recherche-action.

\section{ERREFERENTZIAK}

Bisquerra, R. (2009). Metodología de la investigación educativa (2.ed). Madrid: La Muralla.

Blaxter, L., Hughes, C. eta Tight, M. (2008). Consideraciones sobre los métodos en ¿Cómo se investiga? Barcelona: Graó.

Bolívar, A. (2006). Familia y escuela: dos mundos llamados a trabajar en común. Revista de Educación, 339, 119-146.

Bronfenbrenner, U. (1987). La ecología del desarrollo humano. Barcelona: Paidós.

Comellas, M. J. (2009). Educar en la comunidad y en la familia. Acompañando a las familias en el día a día. Valencia: Nau Llibres.

Colás, P. eta Contreras, J.A. (2013). La participación de las familias en los centros de Educación Primaria. Revista de Investigación Educativa, 31 (2), 484-499.

Cooper, H. (2001). The battle over homework. Common ground for administrators, teachers, and parents. California: Corwin Press.

Cuesta, J.D. eta Hernández, F. (2009) Métodos cuantitativos de investigación. In M.P. Colás, L. Buendía eta F. Hernández (Zuz). Competencias científicas para la realización de una tesis doctoral. Guía metodológica de elaboración y presentación. A Coruña: Davinci Continental.

Department of education and the arts Queensland Australia (2004). Homework Literature Review Summary of key research findings. http://education.qld.gov. au/review/pdfs/homework-text-for-web.pdf - 2016ko ekainaren 27an kontsultatua.

Epstein, J.L. (2001). School, family and community partnerships. Preparing educators and improving schools. Colorado: Westview Press.

Epstein, J.L., Sanders, M.G. eta Sheldon, S.B. (2009). School, Family and Community partnerships: Your handbook for action (3.ed): Thousand Oaks, CA: Corwin Press.

Epstein, J.L. eta Van Voorish, F.L. (2001). More than minutes: Teachers roles in designing homework. Educational Psychologist, 36, 181-193.

Epstein, J.L. eta Van Voorhis, F.L. (2012). The changing debate: From assigning homework to designing homework. In S. Suggate, eta E. Reese (Eds.), Con- 
temporary debates in child development and education (263-273). London: Routledge.

García Bacete. F.J. (2003) Las relaciones familia-escuela: un reto educativo. Infancia y aprendizaje 26 (4), 425-437.

Gimeno Sacristán, J. (2008). El valor del tiempo escolar. Madrid: Morata.

Gómez, J., Latorre, A., Sánchez, M., eta Flecha, R. (2006). Técnicas de recogida de información de orientación comunicativa. In J. Gómez, A. Latorre, M. Sánchez eta R. Flecha. Metodología comunicativa crítica. Barcelona: El Roure.

González, P., Carolina, P., eta Reina, A. (1997). Los deberes, ¿instrumentos de aprendizaje o una pesada carga?. In Lacasa, P., Catálogo de investigaciones educativas 1997-1998. Los deberes escolares: ¿un camino para establecer puentes entre la escuela y la familia? Madrid: Ministerio de Educación y Cultura.

Jolonch, A. (2005). Educación e infancia en riesgo. Acción y reflexión en el ámbito social. RES: Revista de Educación Social, 4, 1-9.

Latorre, A. (2003). Investigación acción. La investigación-acción. Conocer y cambiar la práctica educativa. España: Graó.

Lukas, J. F. eta Santiago, K. (2016). Hezkuntza-ebaluazioa. Bilbao: UPV/EHU.

Moreno, D., Estévez, E., Murgui, S. eta Musitu, G. (2009). Relationship between family and school environments: The role of empathy, attitude to authority and violent behavior in adolescence. International Journal of Psychology and PsychologicalTherapy, 9 (1), 123-136.

Patall, E., Cooper, H. eta Robinson, J. C. (2008). Parent involvement in homework: A research synthesis. Review of Educational Research, 78, 10391101.

Rekalde, I., Vizcarra, M.T. eta Macazaga, A.M. (2011). La aventura de investigar. Una experiencia de investigación-acción participativa. Aula Abierta, 39 (1), 93-104.

Rekalde, I., Vizcarra, M. T. eta Macazaga, A. M. (2014). La observación como estrategia de investigación para construir contextos de aprendizaje y fomentar procesos participativos. Educación XXl, 17 (1), 201-220.

Santiago, K., Lukas, J.F. (2004). Ikerkuntza-proiektua. Tantak 31, 45-67.

Suárez, N., Regueiro, B., Tuero, E., Cerezo, R. eta Rodriguez, C. (2014) La implicación familiar en el ámbito educativo como herramienta para trabajar el éxito académico. Revista de psicología y educación, 9 (2), 83-93.

Thin, D. (2009). Un travail parental sous tension : les practiques des familles populaires à la l'epreuve des logiques scolaires. Informations sociales, 150, 7076.

Ucar, T. eta Iriarte, A. (2012). Etxerako lanak. Idea 38 (5) 6-7 http://consejoescolar.educacion.navarra.es/web1/ficheros-2/revistas-idea/2016ko ekainaren 27 an kontsultatua.

Valanzuela, C. eta Sales, A. (2016). Los efectos de la participación familiar dentro del aula ordinaria. Revista nacional e internacional de educación inclusiva, 9 (2), 71-86.

Van Voorhis, F.L. (2003). Interactive Homework in Middle School: Effects on Family Involvement and Science Achievement. The Journal of Educational Research, 96 (6), 323-338.

Van Voorhis, F.L. (2004). Reflecting on the Homework Ritual: Assignments and Designs. Theory into Practice, 43 (3), 205-212. 